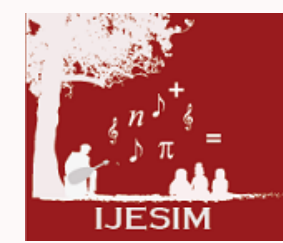

International Journal of Educational Studies in Mathematics

ISSN: 2148-5984

\title{
Investigation of Prospective Elementary Mathematics Teachers' Learning Styles and Relationships between Them Using Data Mining
}

\author{
Serkan Narli ${ }^{1}$, Esra Aksoy ${ }^{2}$, Yusuf Emre Ercire ${ }^{3}$ \\ ${ }^{1}$ Dokuz Eylül University, Buca Education Faculty, Department of Primary Mathematics Education, Izmir, TURKEY \\ 2,3Teachersat Ministry of Education (Master Student), Manisa, TURKEY
}

\section{ABSTRACT}

\begin{abstract}
One of the general discussion in the studies about learning style is what degree of students whose learning style is determined, have other learning styles. In this context, the aim of this study is to determine the learning styles of prospective elementary mathematics teachers and to explore the relationships between these styles by using data mining techniques. Data mining can be defined as applications of different algorithms to identify patterns and relationships in a data set. For this purpose, Grasha-Reichmann Learning Styles Inventory was applied to 400 prospective elementary mathematics teachers at Dokuz Eylul University. Cronbach's alpha reliability coefficient of the scale was found as 0.83.Results show that more than $50 \%$ of female students have "independent" learning style. At the same time students who have competitive learning style had the least number of students. The male students who have collaborative and dependent learning styles were the majority.. From Class 1 to Class 4 , it was observed that the number of students who have individual learning styles was decreasing and the number of students who have cooperative learning styles was increasing. In network graph, it was found that one of the strongest relationships was between the students who have cooperative and independent learning style with high level. On the other hand the relationship between the students who have passive and independent learning style with low level was not seen in graph. The decision tree indicates that the most effective attribute is independent learning style to identify which level of the learning style students have. Besides in the Data mining, learning styles, Mathematics Education association rules model several rules are constructed with $\% 75$ confidence.
\end{abstract}

Keywords:

Data mining, learning styles, Mathematics Education

(C) 2014 IJESIM. All rights reserved

Article History:

Received 28.02.2014 Received in revised form15.04.2014 Accepted 13.05.2014 Available online 01.06.2014

\section{Extended Summary}

With the transition to learner-centered education, approaches related to teaching and learning began to be questioned and developed in education system. The fundamental basis of the change is individual features of students and effect of these features to educational environment.

Teachers can use individual differences in planning learning environments and processes (Tomlinson, 1997: 25). These individual differences consist of a lot of feature such as learning style. Kolb (1984) defines learning style as a preferred way of gathering information, whereas for Dunn (1984) learning style is an individual way of absorbing and retaining information or skills. Özer (1998) reported that teachers must know students' learning styles for effective learning.

\footnotetext{
${ }^{1}$ Corresponding author's address: Dokuz Eylül University, Buca Education Faculty, Department of Primary Mathematics Education, Izmir, TURKEY

Telephone: +905055250017

Fax: +90 2324204895

e-mail: serkan.narli@deu.edu.tr

http://dx.doi.org/10.17278/ijesim.2014.01.004
} 
Like the variety of definitions, there are many learning style models in current literature. And many instruments have been developed to determine students' learning style. The instrument used in this study is Grasha-Riechmann Student Learning Style Scale which was developed to assess six student learning styles. These styles are Independent, Dependent, Avoidant, Participant, Collaborative, and Competitive. According to this learning style approach, learning styles can be classified as:

- Participant-Avoidant

- Competitive-Collaborative

- Dependent - Independent

The Participant/avoidant dimensions of this approach measure how much a learner wants to become involved in the classroom environment, his or her reactions to classroom procedures, and attitudes towards learning. The collaborative/competitive dimensions measure the drives that learners have while interacting with others. The third dimension is being independent/dependent, and it measures how much a learner wants freedom or control the learning environment and, his or her attitudes towards teachers (Jonassen \& Grobowski, 1999).

Using scales of learning style we can identify dominant learning style of students. However according to Denig (2004), individual has non-dominant learning style besides dominant learning style. And one of the general discussion current studies about learning style is what degree of students whose dominant learning style is determined, have other learning styles. In this context, the aim of this study is to determine the learning styles and to explore the relationships between these styles. Unlike conventional methods, data mining techniques were applied to data collected from students in this study.

Data mining can be defined as applications of different algorithms to identify patterns and relationships in a data set. It has been used in different areas. One of these areas is educational environment. As a result of application of data mining techniques in education, educational data mining field has emerged.

This study was conducted by descriptive statistical method. The descriptive statistics are composed of a set of procedures that can be applied to summarize data, enabling the researcher to make comparisons and correlations (Merriam \& Simpson, 2000). The research sample consists of 437 prospective elementary mathematics teachers from Dokuz Eylül University. SPSS and SPSS Clementine programmes were used to analyze collected data. Data mining techniques such as decision tree and association rules were implemented. Furthermore web graph was used for visualition of relationship between learning styles.

The results of the analysis showed that more than $50 \%$ of female students have "independent" learning style. At the same time students who have competitive learning style had the least number of students. The male students who have collaborative and dependent learning styles were the majority. From Class 1 to Class 4, it was observed that the number of students who have individual learning styles was decreasing and the number of students who have cooperative learning styles was increasing.

Network graph shows the relations among the variables. The thickness of the lines between the two variables shows the strength of the relationship between them. Using network graph, it was found that one of the strongest relationship was between the students who have cooperative and independent learning style with high level. On the other hand the relationship between the students who have passive and independent learning style with low level was not seen in graph. It means there was no relationship between these variables.

A decision tree is a flowchart-like tree structure, where each internal node (nonleaf node) denotes a test on an attribute, each branch represents an outcome of the test, and each leaf node (or terminal node) holds a class label. The topmost node in a tree is the root node (Han \& Kamber, 2000). Constructed decision tree models with C5.0 algorithm revealed that the most effective attribute is independent learning style to identify which level of the learning style students have since level of independent learning style is the starting node.

Association rule model finds interesting associations or correlation relationship among large data set of data items (Han \& Kamber, 2000). Association rules use the criteria of support and confidence. By setting minimum confidence 0.75 and support to 0.10 four rules were acquired. After analyzing generated 
association rules it is observed that 76 percent of students who have dependent learning style with medium level and studying in 2nd year, have independent learning style.

The relationship among learning style and other attributes has been investigated in literature. So this study is important to examine learning styles and explore relationships among these styles. Moreover using data mining techniques for investigation is a novel approach for educational domain. Thus interesting patterns in educational data can be revealed and can be used for educational environments. In this study besides determination of dominant learning styles, the relationship among other styles was examined and useful information was acquired using data mining techniques. 


\title{
Veri Madenciliği ile İlköğretim Matematik Öğretmen Adaylarının Öğrenme Stillerinin ve Aralarındaki İlişkilerin İncelenmesi
}

\author{
Serkan Narlı1, Esra Aksoy², Yusuf Emre Ercire ${ }^{3}$ \\ ${ }^{1}$ Dokuz Eylül Üniversitesi Buca Ĕ̆itim Fakültesi İlköğretim Matematik Eğitimi ABD, İzmir, TüRKİYE \\ 2,3MEB' da Öğretmen (Yüksek Lisans Öğrencisi), Manisa, TüRKIYYE
}

ÖZ

\begin{abstract}
Öğrenme stili çalışmalarında genel tartışma konularından biri, herhangi bir öğrenme stiline dâhil edilen öğrencinin diğer öğrenme stillerine ne derece sahip olduklarıdır. Bu bağlamda, bu çalışmanın amacı ilköğretim matematik öğretmen adaylarının öğrenme stillerini belirlemek ve bu stiller arasındaki ilişkileri very madenciliği yöntemleri ile ortaya çıarmaktır. Veri madenciliği bir veri kümesinde örüntülerin veya ilişkilerin bulunması için çeşitli algoritmaların uygulaması olarak ifade edilebilmektedir. Bu amaçla, Dokuz Eylül Üniversitesinde ilköğretim matematik öğretmenliğinde okuyan 400 öğrenciye, Grasha-Reichmann Öğrenme Stilleri Envanteri uygulanmıştır. Ölçeğin güvenirlik katsayısı Cronbach Alfa katsayısı 0,83 olarak bulunmuştur. Veriler incelendiğinde, kız öğrencilerin \%50'den fazlasının "bağımsız", en az frekansla daha "rekabetçi" öğrenme stiline sahip oldukları görülmüştür. Erkeklerde ise işbirlikçi ve bağımlı öğrenme stillerine sahip öğrenci sayısı en fazladır. 1. sınıftan 4. Sınıfa doğru ise, bağımsız öğrenme stiline sahip olan öğrenci sayısının azaldığı, işbirlikçi öğrenme stiline sahip olan öğrenci sayısının arttığı gözlemlenmiştir. A ̆ğ grafiği incelendiğinde, en güçlü ilişki aynı anda bağımsız öğrenme stili ve işbirlikçi öğrenme stilinin yüksek olması ilişkisidir. Diğer bir yandan pasif öğrenme stilinin ve bağımsız öğrenme stilinin düşük düzeyleri arasındaki ilişkinin grafikte yer almadığı görülmüştür. Karar ağacı modeline bakıldığında ise öğrencilerin öğrenme stillerine hangi düzeyde sahip olduklarını belirleyen en önemli özelliğin bağımsız öğrenme stili olduğu görülmektedir. Ayrıca birliktelik kuralları tekniği ile \%75 güvenirlikle çeşitli kurallar oluşturulmuştur.
\end{abstract}

Anahtar Kelimeler:

Veri madenciliği, öğrenme stilleri, matematik eğitimi

(C) 2014 IJESIM. Tüm hakları saklıdır.

Alındı 28.02.2014 Düzeltilmiş hali alındı15.04.2014 Kabul edildi 13.05.2014 Çevrimiçi yayınlandı 01.06.2014

\section{Giriş}

Öğrenme merkezli eğitime geçiş ile birlikte, eğitim sistemlerinde öğrenme ve öğretmeye ilişkin yaklaşımlar hızla sorgulanmaya ve geliştirilmeye başlanmıştır. Değişimin temel dayanağını öğrencilerin farklı bireysel özelliklerinin varlığı ve bunların öğrenme ortamını etkilemesi düşüncesi oluşturmaktadır. Uygulamada bireysel farklılıklar göz önüne alınarak, öğrenci gereksinimlerine uygun eğitimin düzenlenmesi güncel tartışma ve araştırma konusu olmuştur (Tomlinson, 1997; Unesco, 2004).

Bilindiği gibi öğrenciler, hazır bulunuşluk, ilgi ve öğrenme profili gibi temel alanlarda bireysel farklılıklar gösterirler. Öğretmenler, öğrencilerin bu bireysel farklılıklarını öğrenme ortam ve sürecini planlamada kullanabilirler (Tomlinson, 1997). Çünkü tam öğrenme süreci, öğrencilerin bireysel farklılarının göz önüne alınmasını gerektirir. Başka bir deyişle öğrencilerin nasıl öğrendiği, güçlü yanlarının ve sınırlılıkların ne olduğu ile ilgili bilgiler sistemin kurgulanmasında yardımcı olur. Özet olarak öğrenme profili; cinsiyet, kültür, zekâ türü, dil tercihi ve öğrenme stili gibi öğrenmeyi etkileyen birçok unsuru içerir (Unesco, 2004). Öte yandan öğrenme sürecinin iki bileşeni olarak görülen zekâ ve öğrenme stili eğitimde önemli bireysel farklılıklar olarak varsayılır (Kuzgun \& Deryakulu, 2006). Bu nedenle eğitimde, bireysel zekâ ve öğrenme stili farklılıkları etkin kavramlar sayılır ve öğrenme sürecinin tüm aşamalarında göz önüne alınırlar.

\section{Öğrenme Stilleri}

Bireyler arası farklılıkları oluşturan önemli bir bileşen bireysel öğrenme stilidir. Kolb (1984) öğrenme stilini; "bilginin algılanması ve işlenmesi sürecinde bireyin tercih ettiği yol" diye tanımlamaktadır. Buna 
paralel olarak, öğrenme stili "her bireyde farklılık gösteren, yeni ve zor bir akademik bilgiyi işleme, özümseme ve anımsama sürecinde kullanılan yol" (Dunn, 1983) olarak da tanımlanır. Buna göre öğrenme stili; "bir bireyin öğrenme ortamını psikolojik olarak nasıl algıladığını, çevresi ile nasıl etkileşimde bulunduğunu ve nasıl tepki verdiğini belirleyen faktörler kümesidir" olmaktadır. Öğrenme stili ile ilgili başka tanımlar da yapılmaktadır. Öğrenme stili tanımlarında ortak yanların yanı sıra farklı boyutlar da öne çıkarılmaktadır (Şimşek, 2006).

Öğrenme stilleri, öğrencilerin, öğrenme çevresini nasıl algıladıklarını, bu çevreyle nasıl etkileşim kurduklarını, nasıl tepki verdiklerini ortaya koyan tercihleridir ve bireylerin öğrenme süreci içerisinde öğrenmeyi nasıl geçekleştirdikleri ile ilgilidir (Şimşek, 2007). Sternberg'e göre öğrenme stili; bireyin hangi biçimde öğreneceğine ilişkin bireysel tercihi, Reiff'e göre ise bireyin öğrenmesini kolaylaştıran etmenler, davranışlar ve tutumların kümesidir (Elçi, 2008).

Özer (1998)'e göre etkili bir öğrenmenin gerçekleşebilmesi için öğretmenlerin öğrencilerin öğrenme stillerinin ne olduğunu bilmeleri gereklidir. Öğretmenler öğretim etkinliklerini planlamada, eğitim ortamlarını düzenlemede, eğitim ortamında kullanılacak araçları ve gereçleri seçmede, çalışma kümelerini oluşturmada, çalışmalara rehberlik yapmada öğrencilerin öğrenme stillerini göz önünde bulundurmalıdır.

$\mathrm{Bu}$ yüzden de öğrenme sitillerini belirleyebilecek birçok model geliştirilmiştir. Bunlardan biri de Grasha-Reichmann modelidir. Grasha (2002) öğrenme stilini, bireyin bilgi alma becerisini, yaşıtlarıyla ve öğretmenleriyle ilişkisini, öğrenme deneyimlerine katılımını etkileyen kişisel özellikler olarak tanımlamaktadır. Grasha-Reichmann modeli 3 eksende 6 öğrenme stili boyutundan söz eder. Bunlar, bağımlı - bağımsız öğrenme stilleri, katılımcı - pasif öğrenme stilleri ve işbirlikçi - rekabetçi öğrenme stilleridir. Grasha-Riechmann Öğrenci Stili Ölçeği'nde yer alan altı boyutun kendine özgü özellikleri aşağıda verilmiştir (Şentürk, 2010):

Tablo 1.Grasha-Riechmann öğrenme stilleri ve özellikleri

\begin{tabular}{cl}
\hline Öğrenme Stilleri & \multicolumn{1}{c}{ Özellikleri } \\
\hline Rekabetçi & -Materyali sınıftaki öğrencilerden daha iyi hazırlayıp sunmak için öğrenir. \\
& -Diğer öğrencilerle ödül almak ya da öğretmenin ilgisini çekmek için yarışır. \\
& -Sınıf, kendisinin her zaman kazandığı kazanma-kaybetme ortamıdır. \\
\hline İşbirlikçi & -Düşünme ve becerileri paylaşarak en fazla ve en iyi öğrenir. \\
& -Sınıf sosyal etkileşim yeridir. \\
& -Öğretmen ve arkadaşlarıyla işbirliği içindedir, işbirliğinden hoşlanır. \\
\hline Pasif & -Geleneksel öğretim ortamında ders ve dersin içeriğiyle ilgilenmeyen öğrenci tipidir. \\
& -Sınıftaki öğrencilerle ve öğretmenle paylaşımda bulunmaz. \\
& -Sınıfta ne olup bittiğine karşı ilgisizdir. \\
\hline Katılımcı & -Ders konularına ve öğrenmeye karşı isteklidir ve okula gitmekten hoşlanır. \\
& -Sınıfın dışında bilgi getirme sorumluluğunu üstlenmeye isteklidir. \\
& -Edindiği bilgiyi istenildiğinde sınıfla paylaşır. \\
\hline Bağımlı & -Entelektüel merakı çok azdır, sadece ne istenirse onu öğrenir. \\
& -Öğretmen ve diğer öğrencileri bu yapılanmanın kaynağı ve desteği olarak görür. \\
& -Öğretmeni her zaman yönlendirici ve rehberlik eden, kendisini de ne denirse onu \\
& yapan olarak görür. \\
\hline Bağımsız & -Kendisi için düşünür. \\
& -Kendi basına çalışmayı tercih eder, ancak sınıfta diğerlerini de dinler. \\
& -Kendi öğrenme yeteneğine güvenir. \\
\hline
\end{tabular}

Öğrenme stilini belirleyen araçlarda ve bunların bağlı olduğu öğrenme stili modellerinde, bireysel öğrenme stilleri sayısının bilindiği ve bireyin öğrenme stilinin değişmeyeceği vurgulanır. Buna karşın Silver, Strong \& Perini (1997), bireysel öğrenme stilinin yaşam boyunca sabit olmadığını, bireyin öğrenme düzeyi ve büyümesiyle geliştiğini belirtir. Onlara göre bireyin öğrenme stili, stillerin bir bileşiminden oluşur.

Öğrenme süreci aşamalarından biri ya da birkaçında bireyin tercihleri diğer bireylerden ayrılabilir. Bu farklılık, bireyin öğrenme tercihi ile ilgilidir. Her bireyin, baskın olan öğrenme stili vardır. Birey baskın 
öğrenme stilinin yanında baskın olmayan öğrenme stiline de (ikincil, üçüncül...) sahiptir (Denig, 2004). O nedenle öğrenme sürecinin herhangi bir aşamasında birey değişik yaklaşımlar sergileyebilir. Bireyin sahip olduğu baskın öğrenme stili, farklı bileşenlerden oluşur. Bu doğrultuda, örneğin Garner (2000), Kolb öğrenme stillerinde problemler ve tutarsızlıkların olduğunu ve stillerde sabitlikten öte esnek bir yapının olduğunu vurgular. Benzer şekilde Kolb, geçmiş teorik ve deneysel çalışmaların belirttiği orijinal dört öğrenme stilinin, dokuz farklı öğrenme stiline genişletilebileceğini belirtmektedir. Ayrıca Curry'e (1990) göre öğrenme stiline ilişkin çalışmalar, tanım, ölçek ve güvenilirlik alanında kimi problemleri de içermektedir.

Matematik öğretmenlerinin öğrenme stilinin önemine inanması, temellerini içselleştirmesi gerekir. Bu yolla öğrenme stiline dayalı öğrenme süreci tasarlamaları ve geliştirmeleri gerçekleşebilir. Bunun için önce, matematik öğretmen ve öğretmen adaylarının kendi öğrenme stillerini ve özelliklerini kapsamlı olarak bilmeli ve tanımalıdır. Matematik öğretmen adaylarının öğrenme stillerinin belirlenmesine ve öğrenme stiline dayalı öğrenme süreçlerinin incelenmesine yönelik araştırmaların (Ali \& Kor, 2007; Elçi, 2008; Ertekin, Dilmaç \& Yazıcı, 2009; Fer, 2003; Küçükkaragöz, et al., 2009; Orhun, 2007; Peker, Mirasyedioğlu \& Aydın, 2004; Peker, 2009; Perry \& Ball, 2004) yapıldı̆̆ı bilinmektedir. Ancak, öğrenme stili modellerinin temellerindeki farklılıklar ve ölçme araçlarının yapısı ve belli değerlendirmeler nedeniyle öğrenme stillerinin esnek yapısı tam olarak görülememektedir. Bunun sonucunda öğrenciler üç ya da dört sabit öğrenme stili içinde sinıflandırılmaktadırlar.

Oysa öğrenme stilleri arasında en iyi, tek bir doğru stil gibi tanımlama yapmak doğru değildir. Bireyin baskın olan ve olmayan öğrenme stilinin kapsamlı olarak belirlenmesi ve sahip olduğu bu çoklu yaklaşımın öğrenme sürecinde kullanılması gerekir. Bu durumda öğrenciler, öğrenme stillerine göre kesin olarak sınıflandırılabilirler mi? Herhangi bir öğrenme stiline baskın olarak sahip olan bir öğrenci diğer öğrenme stillerine ne derece sahiptir? Baskın stiller ile diğerleri arasındaki ilişkiler nelerdir? Bu tür soruların, matematiksel olarak kesin sınır içermeyen belirsiz kavramları içerdiği düşünülebilir. Bu sorulara yanıt vermek üzere, öğrencilerin bireysel farklılıklarından biri olan öğrenme stilini belirlemede, geleneksel yöntemlerden farklı olarak bulanık mantık kullanılarak öğrenme stillerinin modellendiği yaklaşımlar da görülmektedir. Yapılan çalışmalarda, bulanık mantıkla bir öğrencinin öğrenme stilinin nasıl bulunacağı ve öğrenme ortamlarıyla ilgili belirsizliklere çözüm getirmesi hedeflenmiştir (Kazu \& Özdemir, 2009; Özek, Akpolat \& Orhan, 2010; Uysal, 2010). Ayrıca araştırmacılar, öğrenenlerin öğrenme stillerini tek tip öğrenme stili ile sınırlamanın mümkün olmadığını, bunların zamanla belirli ölçüde değişebileceğini, öğretim uygulamaları ya da öğretim durumlarına göre de farklı öğretim tasarımının gerekebileceği göz önünde bulundurulmasını belirtmişlerdir. Sunulan çalışmada ise, mühendislik, askeri, ekonomi, yapay zekâ ve eğitim gibi birçok alanda kullanılan veri madenciliği tekniklerinden yararlanılmıştır. Bu yolla yapılan veri analizinin öğrenme stilleri arasındaki ilişkiyi daha doğru modelleyebileceği varsayılmıştır.

\section{Veri Madenciliği}

Veri madenciliği, veriyi farklı açlardan analiz etmeyi ve bu veriyi kullanışlı bilgiye dönüştürerek özetlemeyi sağlayan veri analizi metodudur. Eğitimsel veri madenciliği ise eğitimsel veri tabanlarından elde edilen veriye, eğitimsel amaçlar doğrultusunda veri madenciliği yöntemlerinin uygulanmasıyla ortaya çıan bir araştırma alanıdır. Şurası da unutulmamalıdır ki bilinen istatistik yöntemleri de veri madenciliği içinde değerlendirilebilir. Yani veri madenciliği teknikleri denildiğinde bilinen istatistik yöntemleri de akla gelmelidir.

Ayrıca veri madenciliği, çok büyük miktardaki gözlenebilir verinin analiz edilmesiyle, beklenmedik veri ilişkilerinin ve sıra dışı sonuçların veri sahibine anlaşılır bir şekilde iletilmesi olarak ta tanımlanmaktadır (Güçle, 2010). 
Buna göre veri madenciliği modelleri aşağıdaki gibi sınıflanabilir (Güçle, 2010):

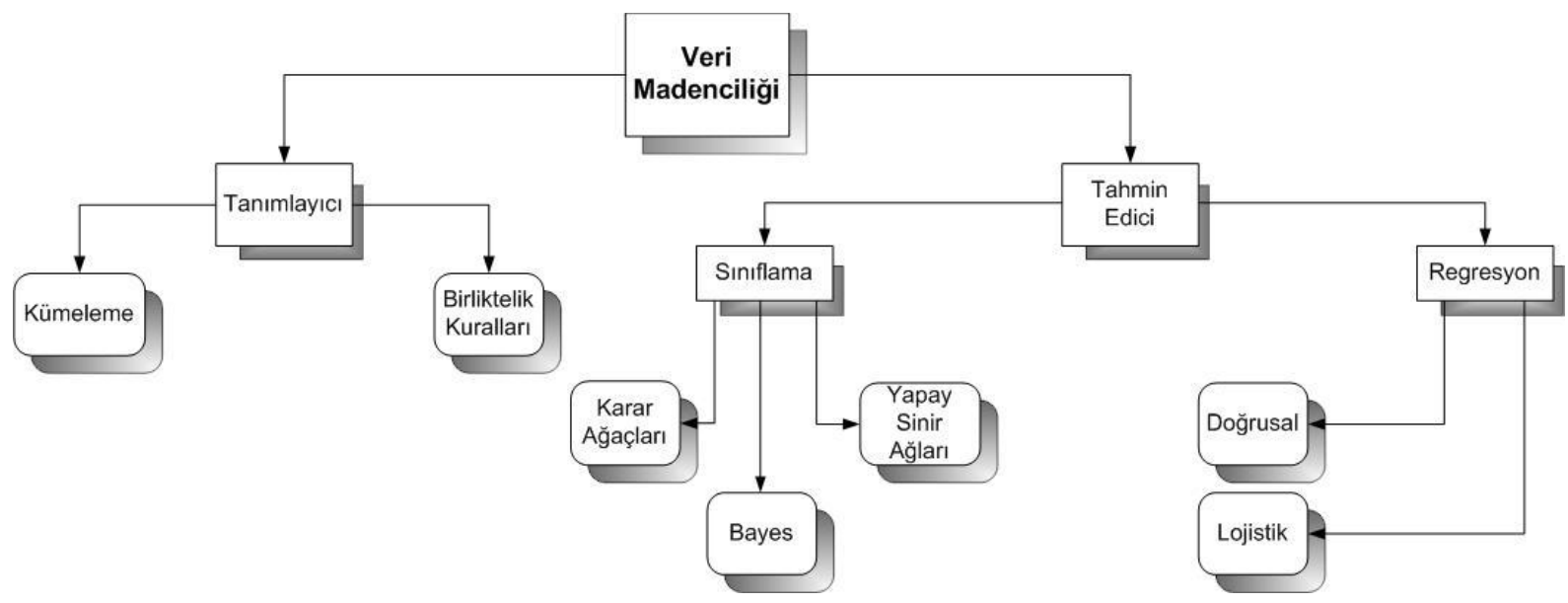

Şekil1. Veri madenciliği modelleri

Son yıllarda, eğitim ile ilgili konulardaki verilerin yorumlanması ile ilgili eğitimsel veri madenciliği (EVM) (educationaldatamining(EDM)) isimli bir çalışma alanı doğmuştur. EVM, eğitimsel bir çevreden elde edilen, öğrencilerin kazanımları ile ilgili verilerin değerlendirilip geliştirilerek, daha anlamlı sonuçların keşfedilmesini sağlayacak yöntemlerin elde edildiği çalışmaları içermektedir (Baker, in press). Bu çalışmalar daha çok eğitimsel verilerin anlamlı kesimlerinin elde edilmesine odaklanmaktadır. Buna karşlık kimi araştırmacılar bunun, öz bilginin öğrenciler tarafından nasıl kullanılabileceği yönünü öne çıkarmaktadırlar (Amarshi\&Conati, 2009). Örnek çalışmalarda veri madenciliğinin, "makine öğrenimi (machinelearning)", "psikometri ve istatistiğin diğer alanları", "bilgi görselleme (informationvisualization)" ve "bilişimsel modelleme (computationalmodeling)" gibi alanlarda kullanılabildiği görülmektedir.

EVM ile ilgili çalışmalarının çoğu öğrencilerin geribildirim ve ip uçlarına ulaştığı etkinlikler olan, problem çözme ya da (e.g., Baker et al., 2008; Sison et al., 2000; Zaiane 2002), alıştırma ve uygulama (drill and practice) yapma (e.g. Beck, 2005) etkinlikleri üzerine yapılandırılmış geleneksel zekâ çalışmalarına odaklanır. $\mathrm{Bu}$ alanda değişik çalışmalara rastlanmaktadır. Örneğin veri madenciliği türlerinden biri olan kaba küme veri analizinin, eğitimde tutum ölçeklerinin veri analizinde kullanılabilirliği tartışılmaktadır (Narli, 2010). Ayrıca yazılı sınav verilerinin yorumlanmasında (Narli \& Ozcelik, 2010), biyoloji de canlılık kavramının yapılanmasının bulanık kaba küme yardımı ile modellenmesinde (Yorek \& Narlı, 2009), doğaya karşı tutumların sınıflandırılmasında (Narli at all, 2010) ve de öğrenme stili ile çoklu zeka arasındaki ilişkiyi araştırmada kaba kümelerin kullanılabildiği görülmektedir (Narli at all, 2011).

Veri madenciliğinin eğitimde uygulandığı diğer bir çalışma da Brezilya'daki bir üniversitede yapılmıştır. Burada müfredat değiş̧ikliklerinin öğrenci üzerindeki etkilerinin tanımlanması ve anlaşılması için EVM uygulanmıştır (Becker ve diğ., 2000). Araştırmacılar değişikliklerin nitel etkisini doğrulayıp; özetleme, birliktelik kuralları ve sınıflama gibi veri madenciliği görevlerini kullanarak bu etkiyi değerlendirmişlerdir.(Aydın,2007)

Diğer bir uygulama ise Singapur Eğitim Bakanlığının özel bir eğitim programı için zayıf öğrencilerin seçilmesi ile ilgilidir. Ma ve diğerleri tarafından 2000 yılında gerçekleştirilen çalışmada, birliktelik kurallarına dayalı olan bir puanlama fonksiyonu geliştirilmiştir. Problemin çözümünün ilk aşamasında C4.5 sınıflama algoritması kullanılarak potansiyel zayıf öğrenciler belirlenmiştir. İkinci aşamada ise her zayıf öğrencinin alması gereken dersler birliktelik analizi kullanılarak belirlenmiştir.(Aydın, 2007)

Maltepe üniversitesi öğrencilerinin belirleyici özelliklerinin "K-Means" algoritması kullanılarak kümelendiği bir çalışma ise 2005 yılında Erdoğan ve Timor tarafından yayınlanmıştır. 2003 yılına ait 722 öğrenci verisinin kullanıldığı çalışmada öğrencilerin üniversiteye giriş sınav sonuçları ile başarıları arasındaki ilişki incelenmiştir. (Aydın, 2007)

Eğitimsel veri madenciliğinin öğrenme stilleri ile ilgili araştırmalarda kullanılmasına örnek olarak Kumar ve Vijayalakshmi (2013) öğrencilerin öğrenme stilleri doğrultusunda davranış ve özelliklerinin 
anlaşılması üzerine bir araştırma yapmış ve iki farklı birliktelik kuralı algoritmasını karşılaştırmışlardır. İşitsel ve görsel öğrenmeden görsel ve dokunsal öğrenmeye doğru bir yön değiş̧irme olduğu sonucuna ulaşmışlar.

Sonuçta veri madenciliğinin kullanılabileceği eğitim alanında problem örnekleri şu şekilde özetlenmiştir ( Berry \& Linoff, 1997):

- Öğrenci profillerine göre başarısını tahmin etme

- Öğrencinin başka bir eğitim kurumuna geçme olasılığını tahmin etme

- Zeki ölçme ve değerlendirme sistemleri için bilgi üretme

- Benzer özelik gösteren örencileri gruplama

- Öğrenme ortamlarının iyileştirilmesine yönelik gerekli araştırmaların yapılması

- Daha etkin e-öğrenme ortamlarının tasarımı için web madenciliği uygulamaları

Dolayısıyla, öğrenme stili alanında öğrencilerden derlenen verilerin veri madenciliği ile irdelenmesinin, daha sağlıklı olacağı, yoruma kolaylık sağlayacağı ve vurgulanan boşluğu doldurabileceği düşünülebilir. Sunulan çalışmanın ortaya çıkışı bu varsayıma dayanmaktadır. Çalışmada, Grasha- Riechmann tarafından 1994'te geliştirilen ve Koçak (2007) tarafından Türkçeye çevrilen “Grasha-Riechmann Öğrenci Öğrenme Stili Ölçeği" ile ilköğretim matematik öğretmen adaylarının öğrenme stilleri belirlenecek ve çeşitli değişkenler açısından baskın stiller ve diğerleri veri madenciliği ile incelenecektir. Bu bağlamda araştırmanın problemi ve alt problemleri şu şekilde belirlenmiştir:

\section{Araștırma Problemi}

“Veri madenciliği yöntemleriyle incelendiğinde, ilköğretim matematik öğretmen adaylarının öğrenme stilleri ve aralarındaki ilişkiler nelerdir?"

\section{Alt Problemler}

$\checkmark$ Cinsiyete göre baskın öğrenme stilleri dağılımı nasıldır?

$\checkmark$ Sınıf seviyelerine göre baskın öğrenme stilleri dağılımı nasıldır?

$\checkmark$ Cinsiyete göre öğrenme stilleri seviyeleri dağılımı nasıldır?

$\checkmark$ Öğrenme stilleri ile diğer değişkenler arasındaki ilişki nasıldır?

$\checkmark$ Öğrenme stillerinin alt boyutlarının kendi aralarındaki ilişkileri nasıldır?

$\checkmark$ Öğrenme stillerinin alt boyutları arasındaki karar ağaçları nasıl oluşmaktadır?

$\checkmark$ Öğrenme stilleri ile diğer değişkenler arasındaki birliktelik kuralları nelerdir?

$\checkmark$ Öğrenme stillerinin alt boyutları arasındaki birliktelik kuralları nelerdir?

\section{Yöntem}

Sunulan çalışma tarama modelli betimsel bir araştırmadır. Bu tür araştırmalar, verilen bir durumu aydınlatmak, standartlar doğrultusunda değerlendirmeler yapmak ve olaylar arasında olası ilişkileri ortaya çıkarmak için yürütülür (Çepni, 2009). Modelde, olmuş ya da sürmekte olan bir durumun betimlenmesi amaçlanır. Araştırmaya konu olan olay, birey ya da nesnenin kendi koşulları içinde olduğu gibi tanımlanması araştırmanın özünü oluşturur (Karasar, 2008). Burada da öğrencilerin öğrenme stilleri ve bu öğrenme stillerinin alt boyutları arasındaki ilişki veri madenciliği yöntemleri ile incelenecektir.

\section{Çalışma Grubu}

Araştırmanın örneklemini İzmir Dokuz Eylül Üniversitesi Eğitim Fakültesi İlköğretim Matematik Öğretmenliği 1., 2., 3. ve 4. sınıf öğrencilerinden toplam 437 kişi oluşturmaktadır. 


\section{Veri Toplama Aracı}

Araştırmada öğrenme stili ölçeği olarak Grasha-Riechmann tarafından 1994'te geliştirilen ve Koçak (2007) tarafından Türkçeye çevrilen ‘Grasha-Riechmann Öğrenci Öğrenme Stili Ölçeği kullanılmıştır.

Grasha-Riechmann Öğrenci Öğrenme Stili Ölçeği beşli likert ölçeği seklinde düzenlendiğinden, çözümlemenin yapılabilmesi amacıyla her cevap için bir sayı değeri belirlenmiştir. Ölçeğin puanlamasında; kesinlikle katılmıyorum ifadesi 1, katılmıyorum ifadesi 2, kararsızım ifadesi 3, katılıyorum ifadesi 4, kesinlikle katılıyorum ifadesi 5 puan değerindedir. Ölçekte her öğrenme stiline yönelik 7 'şer madde yer almaktadır. Katılımcıların ölçek maddeleri için işaretlediği ifadeye göre puanlar hesaplanmakta ve herhangi bir öğrenme stilinden en yüksek puana sahip olan stil katılımcının baskın öğrenme stilini oluşturmaktadır. Ölçeğin bu çalışmada Cronbach Alfa katsayısı 0,83 olarak tespit edilmiştir.

\section{Verilerin Analizi}

Grasha (2002), ölçekten alınan puanları düşük, orta ve yüksek olarak gruplamış ve bu gruplar için alt ve üst sınırları aşağıdaki gibi belirlemiştir. Bu gruplamaya göre, bir öğrencinin her bir stilde hangi düzeyde olduğu belirlenmiştir.

Tablo 2. Ölçeğe Göre Alınan Puanların Gruplanması

\begin{tabular}{lccc}
\hline & Düşük & Orta & Yüksek \\
\hline Bağımsız & {$[1.0-2.7]$} & {$[2.8-3.8]$} & {$[3.9-5.0]$} \\
Kaçınan & {$[1.0-1.8]$} & {$[1.9-3.1]$} & {$[3.2-5.0]$} \\
İşbirlikçi & {$[1.0-2.7]$} & {$[2.8-3.4]$} & {$[3.5-5.0]$} \\
Bağımlı & {$[1.0-2.9]$} & {$[3.0-4.0]$} & {$[4.1-5.0]$} \\
Rekabetçi & {$[1.0-1.7]$} & {$[1.8-2.8]$} & {$[2.9-5.0]$} \\
Katılımcı & {$[1.0-3.0]$} & {$[3.1-4.1]$} & {$[4.2-5.0]$} \\
\hline
\end{tabular}

Elde edilen veriler SPSS paket programı ve SPSS Clementine programları ile analiz edilmiştir. Clementine veri madenciliği uygulamaları için SPSS tarafından geliştirilmiş görsel modelleme aracıdır. Clementine farklı veri kaynaklarına ulaşıma olanak sağlayan, modelleri hızlı bir şekilde oluşturma ve karşılaştırma olanaklarıyla ön plana çıkan yazılımdır (Aydın, 2007). Ayrıca SPSS programı ile betimsel istatistik yöntemleri de uygulanmıştır.

\section{Bulgular ve Yorum}

Araştırmada öncelikle öğretmen adaylarının sahip oldukları baskın öğrenme stilleri tespit edilmiştir. Bu durum belirlenirken de cinsiyet ve sınıf düzeyleri de göz önünde bulundurulmuştur. Bu bağlamda cinsiyete göre öğrenme stilleri dağılımı aşağıdaki gibidir:

Tablo 3.Cinsiyete Göre Öğrenme Stilleri

\begin{tabular}{llccc}
\hline \multirow{2}{*}{ Öğrenme Stili } & & Cinsiyet & \multicolumn{2}{c}{ Toplam } \\
\cline { 3 - 5 } & & Kız & Erkek & \\
\hline \multirow{2}{*}{ Bağımlı } & Frekans & 59 & 27 & 86 \\
& Cinsiyet içindeki $\%$ & $17,9 \%$ & $25,2 \%$ & $19,7 \%$ \\
\hline \multirow{2}{*}{ Bağımsız } & Frekans & 166 & 23 & 189 \\
& Cinsiyet içindeki \% & $\mathbf{5 0 , 5 \%}$ & $21,5 \%$ & $43,3 \%$ \\
\hline \multirow{2}{*}{ Katılımcı } & Frekans & 14 & 4 & 18 \\
& Cinsiyet içindeki \% & $4,3 \%$ & $3,7 \%$ & $4,1 \%$ \\
\hline
\end{tabular}




\begin{tabular}{llccc}
\hline \multirow{2}{*}{ Pasif } & Frekans & 15 & 17 & 32 \\
& Cinsiyet içindeki $\%$ & $4,6 \%$ & $15,9 \%$ & $7,3 \%$ \\
\hline \multirow{2}{*}{ İşbirlikçi } & Frekans & 63 & 30 & 93 \\
& Cinsiyet içindeki $\%$ & $19,1 \%$ & $28,0 \%$ & $21,3 \%$ \\
\hline \multirow{2}{*}{ Rekabetçi } & Frekans & 12 & 6 & 18 \\
& Cinsiyet içindeki \% & $3,6 \%$ & $5,6 \%$ & $4,1 \%$ \\
\hline \multirow{2}{*}{ Toplam } & Frekans & 329 & 107 & 436 \\
& Cinsiyet içindeki \% & $100,0 \%$ & $100,0 \%$ & $100,0 \%$ \\
\hline
\end{tabular}

Cinsiyete göre öğrenme stillerine baktığımızda kız öğrencilerin \%50'den fazlasının bağımsız öğrenme stiline sahip olduğu görülmektedir. En az sayıda kız öğrencinin de rekabetçi öğrenme stiline sahip olduğu anlaşılmaktadır.

Bağımsız öğrenme stiline sahip öğrencilerin kendilerine güvenleri yüksektir. Ders projelerinde başka öğrencilerle çalışmaktansa, tek başına çalışmayı tercih ederler. Kendi başlarına çalışırken diğger arkadaşlarını da dinlerler. Kendi kendine öğrenme yeteneğine sahiptirler.

Örneklemdeki kız öğrenciler içinde rekabetçi öğrenme stiline sahip öğrenciler az sayıdadır. Bu durum, daha çok ortaokul ve ilkokul düzeyinde görülmesi muhtemel olan, sınıf arkadaşlarından daha iyi performans gösterip akademik ün kazanmak isteme, diğer öğrencilerle ödül almak için yarışma, ilgi odağ olmayı ve sınıfta yaptıklarının dikkat çekmesini isteme gibi özelliklerin üniversite öğrencilerinde az olduğunu gösterebilir.

Erkeklerde ise işbirlikçi ve bağımlı öğrenme stillerine sahip öğrenci sayısı en fazladır. Bilgileri ve becerileri paylaşarak en iyi öğrenen, bireysel değil grup projelerinde çalışmayı tercih eden, arkadaşlarıyla işbirliğinden hoşlanan, sınıfı etkileşim yeri olarak gören işbirlikçi öğrenme stili, erkek öğrencilerde fazladır. $\mathrm{Bu}$ durum, erkeklerin rekabetten ziyade işbirliğine açık olduğu şeklinde yorumlanabilir. Ayrıca, kızlarda yoğun olan tek başına çalışmayı tercih eden bağımsız öğrenme stilinin tersine, grup çalışmalarına ve etkileşime önem veren bağımlı öğrenme stili ve işbirlikçi öğrenme stilinin erkek öğrencilerde baskın olması, cinsiyetler arası farklılık olarak görülebilir.

Çalışmanın 2. Alt problemi için öğrenme stillerinin sınıflara göre dağılımı incelenmiştir. Sınıflara göre öğrenme stillerinin dağılımlarına baktığımızda ise aşağıdaki tablo ortaya çıkmaktadır:

Tablo 3 Sınıf Seviyelerine Göre Öğrenme Stilleri

\begin{tabular}{|c|c|c|c|c|c|c|c|c|}
\hline \multicolumn{9}{|c|}{ Öğrenme Stili } \\
\hline & & Bağımlı & Bağımsız & Katılımc1 & Pasif & İşbirlikçi & Rekabetçi & Toplam \\
\hline \multirow{8}{*}{ Sinif } & Frekans & 13 & 40 & 4 & 4 & 11 & 6 & 78 \\
\hline & Sınıf için. \% & $16,7 \%$ & $51,3 \%$ & $5,1 \%$ & $5,1 \%$ & $14,1 \%$ & $7,7 \%$ & $100,0 \%$ \\
\hline & Frekans & 15 & 57 & 3 & 12 & 22 & 1 & 110 \\
\hline & Sınıf için. \% & $13,6 \%$ & $51,8 \%$ & $2,7 \%$ & $10,9 \%$ & $20,0 \%$ & $9 \%$ & $100,0 \%$ \\
\hline & Frekans & 27 & 64 & 7 & 8 & 31 & 5 & 142 \\
\hline & Sinıf için. \% & $19,0 \%$ & $45,1 \%$ & $4,9 \%$ & $5,6 \%$ & $21,8 \%$ & $3,5 \%$ & $100,0 \%$ \\
\hline & Frekans & 31 & 29 & 4 & 8 & 29 & 6 & 107 \\
\hline & Sınıf için. \% & $29,0 \%$ & $27,1 \%$ & $3,7 \%$ & $7,5 \%$ & $27,1 \%$ & $5,6 \%$ & $100,0 \%$ \\
\hline \multirow{2}{*}{ Toplam } & Frekans & 86 & 190 & 18 & 32 & 93 & 18 & 437 \\
\hline & Sınıf için. \% & $19,7 \%$ & $43,5 \%$ & $4,1 \%$ & $7,3 \%$ & $21,3 \%$ & $4,1 \%$ & $100,0 \%$ \\
\hline
\end{tabular}


Sınıflara göre öğrenme stilleri tablosuna baktığımızda 1.sınıftan 4.sınıfa kadar yüzdelerdeki değişimde iki öğrenme stili dikkat çekmektedir. 1.sınıfların ve 2.sınıfların yarıdan fazlası bağımsız öğrenme stiline sahipken, 3. ve 4.sınıfta bu oran azalarak 4.sınıfta \%27,1'e kadar gerilemiştir. Aynı şekilde 1.sınıfta \%14,1 olan işbirlikçi oranı, 4.sınıfa kadar sürekli artış göstermiş ve son sınıfta \%27,1 olarak tespit edilmiştir.

Uzuntiryaki, Bilgin ve Geban'ın, (2003) “Lise Öğrencilerinin Öğrenme Stillerinin Kimya Başarısı ve Kimya Tutumları Üzerine Etkisi" isimli çalı̧̧masında, 9.sınıf öğrencilerinin çoğunun bağımsız öğrenme stiline sahip oldukları halde, 10.sınıf öğrencilerinin çoğunun bağımlı öğrenme stiline sahip oldukları belirtilmiştir. Bizim çalışmamıza göre, lisans düzeyinde de benzer sonuçlar ortaya çıktığı söylenebilir.

Özellikle 4.sınıfta Kamu Personeli Seçme Sınavi'na hazırlanan öğrencilerin bu sınavda başarılı olmak için daha çok işbirliği içinde oldukları göz önüne alındığında, bu artış normal karşılanabilir. Ancak bağımsız öğrenme stilindeki öğrenci yüzdesindeki azalmanın, üniversite eğitiminin insanları bağımsızlaştıracağı düşüncesinin aksini gösterdiği düşünülebilir.

3. alt problem için öğrenme stillerinin tüm alt boyutları düşük, orta ve yüksek olmak üzere üç gruba ayrılmış; cinsiyet değişkenine göre dağılım tablosu oluşturulmuştur. Sonuçlar Tablo4 de görülebilir:

Tablo 4. Cinsiyete Göre Öğrenme Stili Düzeyleri

\begin{tabular}{|c|c|c|c|c|c|}
\hline & & \multicolumn{4}{|c|}{ Cinsiyet } \\
\hline & & \multicolumn{2}{|c|}{ K1z } & \multicolumn{2}{|c|}{ Erkek } \\
\hline & & Sayı & Yüzde & Say1 & Yüzde \\
\hline \multirow{3}{*}{ Bağımlı Sınıf } & Düşük & 16 & $\% 4,9$ & 7 & $\% 6,5$ \\
\hline & Orta & 234 & $\% 71,1$ & 64 & $\% 59,8$ \\
\hline & Yüksek & 79 & $\% 24$ & 36 & $\% 33,6$ \\
\hline \multirow{3}{*}{ Bağımsız Sınıf } & Düşük & 3 & $\% 0,9$ & 4 & $\% 3,7$ \\
\hline & Orta & 72 & $\% 21,9$ & 46 & $\% 43$ \\
\hline & Yüksek & 254 & $\% 77,2$ & 57 & $\% 53,3$ \\
\hline \multirow{3}{*}{ Katılımcı Sınıf } & Düşük & 93 & $\% 28,3$ & 53 & $\% 49,5$ \\
\hline & Orta & 218 & $\% 66,3$ & 49 & $\% 45,8$ \\
\hline & Yüksek & 18 & $\% 5,5$ & 5 & $\% 4,7$ \\
\hline \multirow{3}{*}{ Pasif Sinıf } & Düşük & 3 & $\% 0,9$ & 1 & $\% 0,9$ \\
\hline & Orta & 211 & $\% 64,1$ & 49 & $\% 45,8$ \\
\hline & Yüksek & 115 & $\% 35$ & 57 & $\% 53,3$ \\
\hline \multirow{3}{*}{ İşbirlikçi Sınıf } & Düşük & 17 & $\% 5,2$ & 10 & $\% 9,3$ \\
\hline & Orta & 85 & $\% 25,8$ & 30 & $\% 28$ \\
\hline & Yüksek & 227 & $\% 69$ & 67 & $\% 62,6$ \\
\hline \multirow{3}{*}{ Rekabetçi Sınıf } & Düşük & 20 & $\% 6,1$ & 8 & $\% 7,5$ \\
\hline & Orta & 126 & $\% 38,3$ & 41 & $\% 38,3$ \\
\hline & Yüksek & 183 & $\% 55,6$ & 58 & $\% 54,2$ \\
\hline
\end{tabular}

Öğrenme stili sınıflarının düzeylerine göre ayrıldığı, yukarıdaki tabloya bakıldığında kızların \%71,1'inin erkeklerin ise \%59,8'inin bağımlı sınıfta orta düzeyde olduğu görülmektedir. Bağımsız sınıfta ise kız öğrencilerin \%77,2 gibi büyük çoğunluğunun yüksek düzeyde olduğu çarpıcı olarak göze çarpmaktadır. Katılımcı sınıfta kızların büyük çoğunluğu orta düzeyde iken erkeklerin $\% 49,5$ 'i düşük düzeydedir. Buna bakarak örneklemdeki üniversite öğrencilerinde erkeklerin derslerde daha az katılımcı olduğu yorumu yapılabilir. Aynı şekilde erkeklerin \%99,1 gibi nerdeyse tamamının orta ve yüksek düzeyde pasif sınıfta olması da bu yorumu güçlendirmektedir. Kızların \%69'u, erkeklerin ise $\% 62,6$ 'sı işbirlikçi sınıfta yüksek düzeyde iken aynı şekilde yarıdan fazlası rekabetçi sınıfta da yüksek düzeydedir. Bu çelişki gibi görülmekle birlikte örneklemin öğretmen adayları olduğu düşünüldüğünde, işbirliğine açık olmaları ve yıllarca sınavlara dayalı sistemlerin getirdiği rekabet ortamı da göz önüne alındığında, sonuç olağan görülebilir. 
Öğrenme stilleri ile cinsiyet, öğrenim türü ve sınıf seviyesi olarak belirlenen diğer değişkenler arasındaki ilişkiyi belirlemek üzere oluşturan alt problem için veri madenciliği tekniklerinden ağ grafiği kullanılmıştır. A ̆̆ grafiği, değişkenlerin birbirleriyle olan ilişkisini gösteren bir grafik türüdür. İki değişken arasındaki çizginin kalınlığı o iki değişkene de sahip kişilerin sayısının fazlalığını vermektedir. Buna göre öğrenme stili ile diğer değişkenler arasındaki ağ grafiği aşağıdaki gibi oluşmuştur:
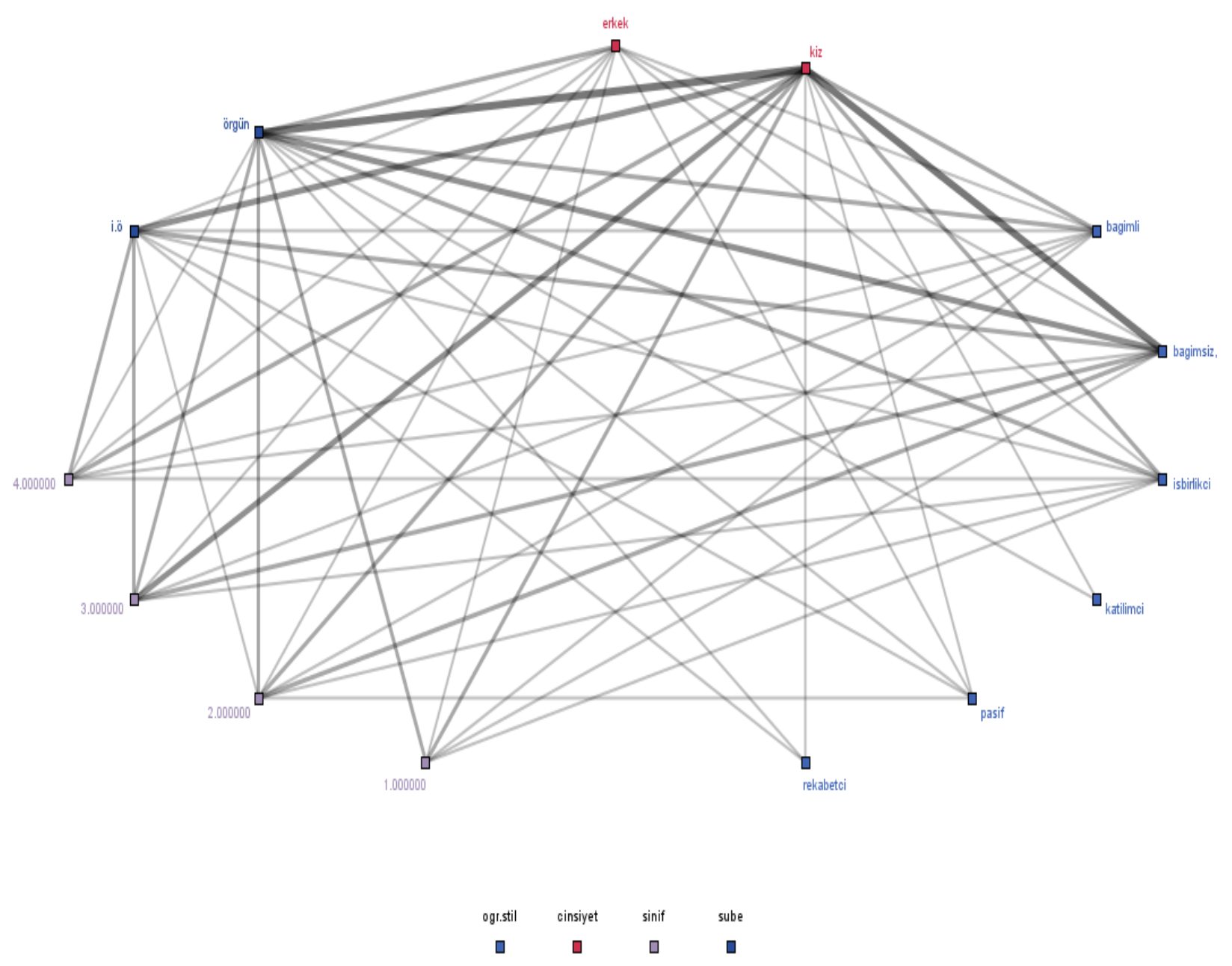

\section{Şekil 2.Ö̆̆grenme Stilleri ve Diğer Değişkenler Arasındaki Ağ Grafiği}

Yukarıdaki grafikte kız-örgün ve kız-bağımsız değişkenleri arasındaki çizgilerin kalınlığı göze çarpmaktadır. Bu da örneklemimizdeki örgün öğretimde öğrenim gören kızların çokluğunu ve bağımsız öğrenme stiline sahip kız öğrencilerin sayısının fazlalığını göstermektedir. 
Öğrenme stillerinin alt boyutlarının aralarındaki ilişkiye ait ağ grafiği ise aşağıdaki gibi oluşmuştur:

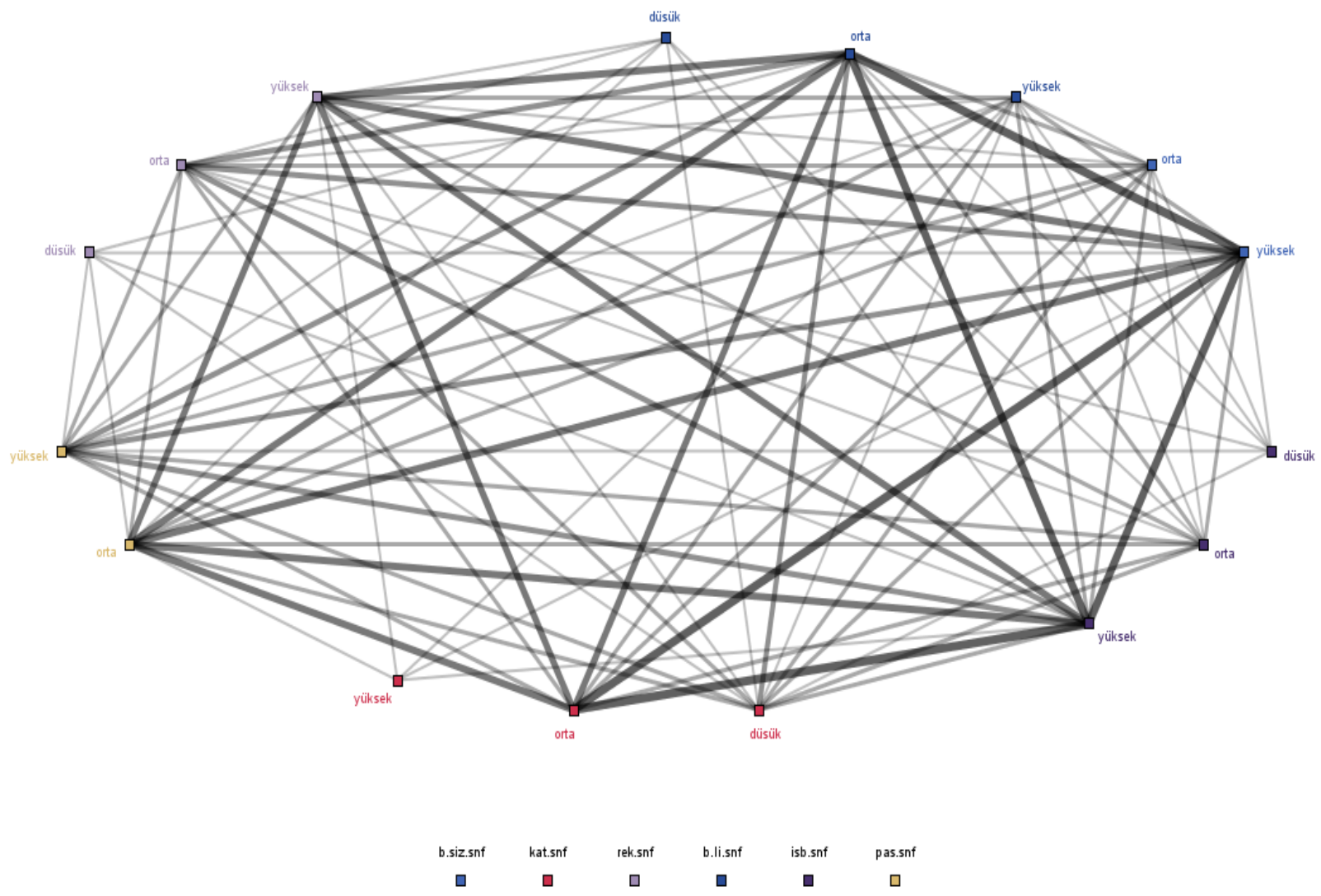

Şekil 3.Öğrenme Stilleri Alt Boyutlarının Birbirleriyle İlişkisi 1

Yukarıdaki ağ grafiğinde ise 6 öğrenme stilinin düşük, orta ve yüksek düzeylerinin birbirleriyle olan ilişkisi görülmektedir. Uçlardaki her bir nokta bir düzeyi göstermektedir. Pasif öğrenme stilinin ve bağımsız öğrenme stilinin düşük düzeylerinin grafikte yer almadığı görülmektedir. Bunun nedeni seçtiğimiz duyarlılıkta anlamlı bir değişken olmamalarıdır. Duyarlılığı daha da düşürerek zayıf ilişkileri grafikten kaldırabiliriz. Bunun için aşağıdaki grafik incelenebilir:

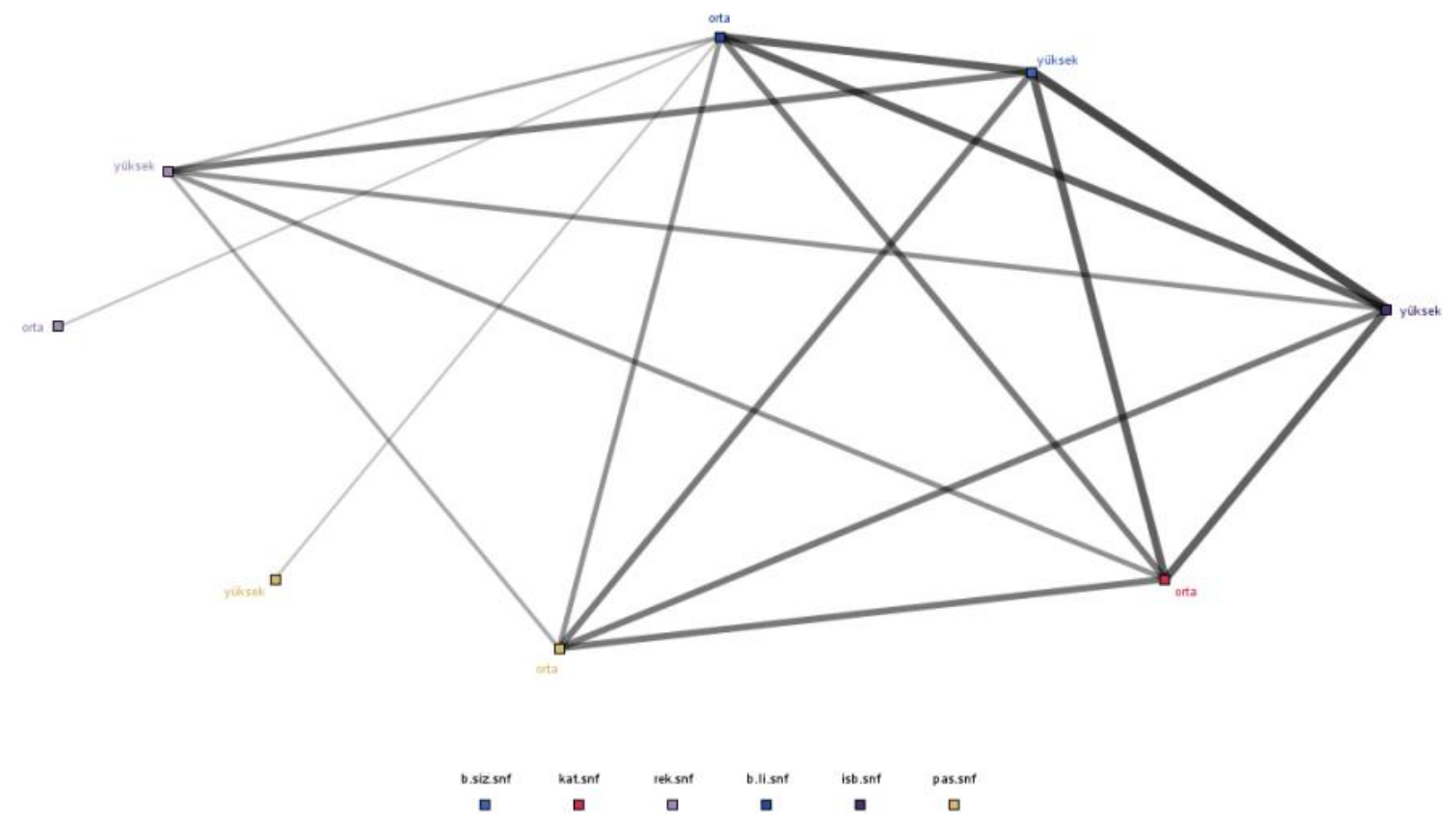

Şekil 4.Öğrenme Stilleri Alt Boyutlarının Birbirleriyle İlişkisi 2 
Yukarıdaki şekilden daha iyi anlaşıldığı üzere, işbirlikçi öğrenme stili düzeyi yüksek olan öğrencilerin bağımlı öğrenme stillerinin orta düzeyde olduğu, bağımsız öğrenme stillerinin ise yüksek düzeyde olduğu görülebilir. Hem rekabetçi stil düzeyi, hem de bağımsız stil düzeyi yüksek olan öğrencilerin çokluğu da aralarındaki çizginin kalınlığına bakılarak anlaşılmaktadır. Katılımcı stil düzeyi orta olup, bağımsız stil düzeyi yüksek olan öğrencilerin de fazla sayıda olması iki düzey arasındaki ilişkinin kuvvetli olduğunu göstermektedir.

En kuvvetli ilişkiyi bulmak için duyarlılığı azalttığımızda, aşağıdaki ağ grafiği elde edilmektedir:
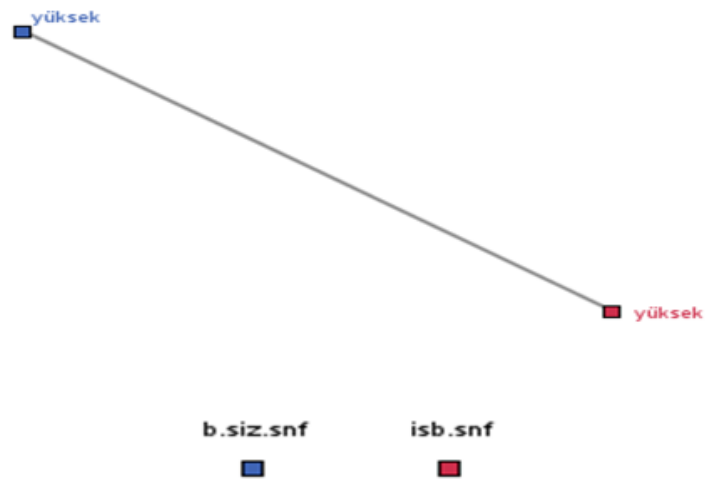

Şekil 5.Öğrenme Stilleri Alt Boyutlarının Birbirleriyle İlişkisi 3

Şekil 5' ten görüleceği üzere, duyarlılık azaltıldığında, bağımsız stilin yüksek düzeyi ile işbirlikçi stilin yüksek düzeyi geriye kalmaktadır. Bu durumda örneklemimizdeki öğretmen adaylarında aynı anda bağımsız öğrenme stili ve işbirlikçi öğrenme stili yüksek olma ilişkisinin diğer düzeyler arasındaki ikili ilişkilerden daha anlamlı olduğu ortaya çıkmaktadır.

Diaz ve Cartnal (1999) yapmış oldukları 'İki Ayrı Sınıfta Öğrenme Stilleri' adlı çalışmada, uzaktan eğitim (on-line) sınıfları ile kampus sınıflarında sağlık eğitimi alan öğrencilerin öğrenme stillerini karşılaştırmışlardır. Kampüste eğitim gören grupta işbirlikçi olan öğrencilerin aynı zamanda daha bağımsız ve katılımcı olduğu, rekabetçi olan öğrencilerin de aynı zamanda katılımcı olmaya eğilimli oldukları bulgusuna ulaşmışlardır. Bizim çalışmamızda da bağımsız öğrenme stili ile işbirlikçi öğrenme stili arasındaki ilişkinin yüksek çıkması ve rekabetçi öğrenme stilinin yüksek düzeyi ile katılımcı öğrenme stilinin orta düzeyi arasındaki ilişkinin yüksek çıkması, Diaz ve Cartnal'ın (1999) çalışmasını destekler niteliktedir.

Diğer alt problem için, öğrenme stillerinin alt boyutları arasındaki ilişkiyi incelemek amacı ile uygulanan bir başka veri madenciliği tekniği ise karar ağaçlarıdır. Karar ağaçları sınıflama, kümeleme ve tahmin görevlerinde kullanılan yaygın bir tekniktir. Bir karar ağacı dügüümler ve dügüüleri birleştiren bağlantılardan oluşan hiyerarşik bir yapıdır. Tahmin edici modellerin sınıflama yöntemlerinden biri olan karar ağaçlarında araştırdığımız sınıfı sağlayan başlangıç düğümüne kök düğüm, ara safhalardaki düğümlere yaprak düğüm, ağacın bittiği düğümlere ise son düğüm adı verilir (Çelik, 2009). Karar ağacının her düğümünde değişkenler test edilir. "Karar ağacı algoritması, ağacın kökünde hangi değişken ile test edilmesi gerektiği sorusu ile başlayarak yukarıdan aşağıya doğru ağacı oluşturur. Bu işlemi her örnek değişken, eğitim örneklerinin sınıflandırmasına karar vermek için istatistiksel test kullanılarak değerlendirilir. En iyi değişken seçilir ve ağacın kök düğümünde test için kullanılır." Her bir düğüm için oluşturulacak dalların sayısı, test sonucunda kabul edilmiş olan değişkenin alabileceği değer sayısına göre farklılaşmaktadır (Kök; Kuloğlu, 2005'den akt: Çelik, 2009). Bu çalışmada elde edilen karar ağacı ise şekil 6 da ki gibidir. 


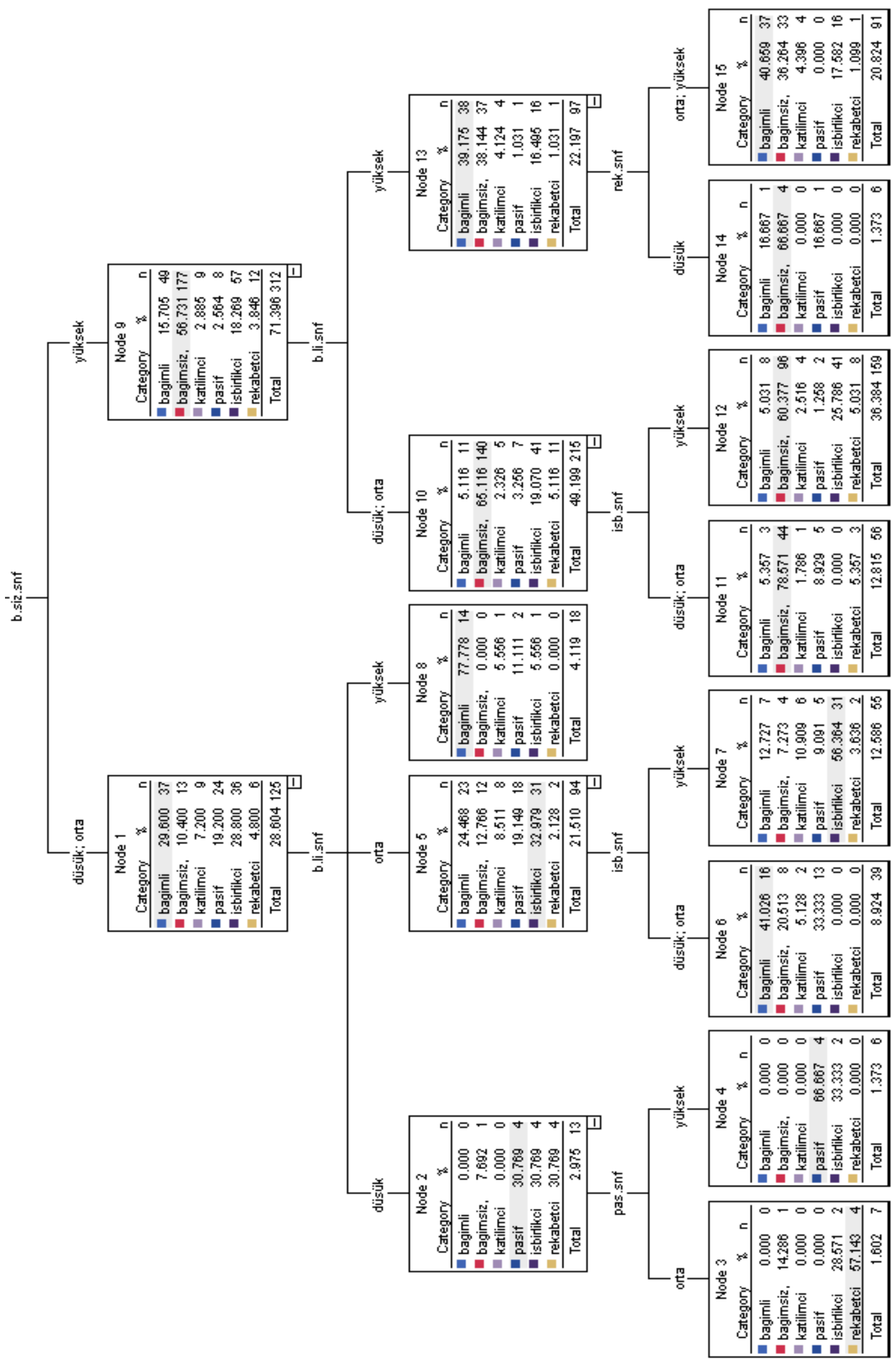

Şekil 6. GrashaRiechmann Öğrenme Stili Alt Boyutları C5.0 Karar Ağacı 
Şekil 6'da kurulan karar ağacı modeline bakılırsa, ölçekten alınan verilere göre, örneklemi oluşturan öğrencilerde, ilk dallanmanın bağımsız öğrenme stiline göre oluştuğu görülmektedir. Bu verilere bakarak eğer elimizde bir öğrencinin öğrenme stili ve alt boyutları ile ilgili bilgiler varsa bu alt boyutlar arasındaki ilişkileri kullanarak ve yaprak düğümleri takip ederek son dügü̈mde bu öğrencinin GrashaRiechmann öğrenme stili alt boyutlarını hangi yüzdelerle taşıyabileceği hakkında bilgi sahibi olabiliriz.

Karar ağacının oluşturulurken veri tekrarlı bir biçimde daha küçük alt kümelere bölünür. Her bir bölmede en uygun bağımsız değişkenin seçimi önemli bir konudur. Burada bağımlı değişkene göre en homojen alt kümeyi oluşturan bölme seçilmiş olmalıdır. Bölme işleminde bağımsız değişkeni seçerken gini indeksi, bilgi kazanımı vb. bazı özellik seçim ölçüleri kullanılır. Bu ölçülere göre yapılan bölme süreci daha uygun bir bölme kalmayana kadar devam eder (Güntürkün, 2007). Bu çalışmada en iyi bölmeyi oluşturmak için bilgi kazanımını kullanan C5.0 karar ağacı kullanılmıştır. Grasha-Riechmann öğrenme stilinin alt boyutları için oluşturulan karar ağacı öğrencilerin bağımsız öğrenme stili düzeylerine göre dallanmaya başlamıştır (bkz. Şekil 6, Node 1 ve Node 9 ). Bu durumda öğrencilerin GrashaRiechmann öğrenme stilinin alt boyutlarında hangi düzeylerde olduklarının belirlenmesinde en etkili değişkenin bağımsız öğrenme stilindeki düzeyleri olduğu söylenebilir.

Karar ağaçlarında kurulan modellerden tahminler gerçekleştirme işlemi ana düğümden en altta dallanmanın söz konusu olmadığı karar düğümüne gidilerek yapılabilir (Bilen, Hotaman, Aşkın \& Büyüklü, 2014). Grasha-Riechmann Öğrenme Stili Alt Boyutları için kurulan ağaç modelinde en yüksek olasılığa sahip karar düğümüne doğru gidersek; bağımsız öğrenme stili yüksek düzeyde (Node 9), bağımlı öğrenme stili düşük veya orta düzeyde (Node 10) ve işbirlikçi öğrenme stili düşük veya orta düzeyde (Node 11) olan öğrencilerin \% 78,57 olasılıkla bağımsız öğrenme stiline sahip oldukları yorumunu yapabiliriz. Diğer karar düğümleri için de bu yöntemle yorum yapılabilir.

Son iki alt problem için, öğrenme stilleri ile diğer değişkenler arasında ve öğrenme stilinin alt boyutları arasındaki birliktelik kuralları araştırılmıştır. Birliktelik kuralları, veri kümesi içindeki hareketlerin analiz edilerek bu hareketler ya da kayıtlar arasında sıklıkla bir arada görülenlerin tespit edilmesi işlemidir (Dolgun 2006). Birliktelik kuralları veri madenciliği modellerinden tanımlayıcı modellerdendir. Tanımlayıcı modellerde, veri kümesindeki örüntülerin bulunması amaçlanmaktadır (Çelik, 2009).

Birliktelik kuralları verideki güçlü birliktelik özelliklerini tanımlayan örüntüleri keşfetmek için kullanılan bir analiz yöntemidir. Keşfedilmiş örüntüler özel olarak çıarılan kurallar veya özellik alt grupları şeklinde temsil edilebilir (Aydın, 2007)

$\mathrm{Bu}$ analizde önemli olan iki kavram destek ve güven kavramlarıdır. Destek, yukarıda belirtilen kural cümlesini sağlayan olayların birlikte gerçekleştiği durumların tüm durumlara oranı iken, güven, kural cümlesini sağlayan olayların birlikte gerçekleştiği durumların öncül bölümde gerçekleşen olaya oranıdır.(Emel, Taşkın ve Tok, 2005).

Öğrenme stilleri ile diğer değişkenler arasındaki birliktelik kuralları aşağıdaki gibi oluşmuştur:

Tablo 5.Öğrenme Stili Ve Diğer Değişkenler Arasında Birliktelik Kuralları

\begin{tabular}{llllc}
\hline \multicolumn{1}{c}{ (Bağlıkoşul) } & \multicolumn{1}{c}{ (Önkoşul) } & Destek \% & Güvenirlik \% & $\begin{array}{c}\text { Kaldıraç } \\
\text { Değeri }\end{array}$ \\
\hline Öğr.stil=bağımsız, & $\begin{array}{l}\text { Sınıf=2 } \\
\text { Bağımlı snf=orta } \\
\text { Bağımsı snf=yüksek }\end{array}$ & 11.899 & 76.923 & 1.769 \\
\hline Öğr.stil=bağımsız, & $\begin{array}{l}\text { İşbirlikçi snf=orta } \\
\text { Bağımlı snf=orta } \\
\text { Bağımsı snf=yüksek }\end{array}$ & 10.297 & 75.556 & 1.738 \\
\hline Öğr.stil=bağımsız, & $\begin{array}{l}\text { Sinıf=2 } \\
\text { pasifsnf=orta } \\
\text { Bağımsız snf=yüksek }\end{array}$ & 12.128 & 75.472 & 1.736 \\
\hline Öğr.stil=bağımsız, & $\begin{array}{l}\text { Sinıf=2 } \\
\text { Bağımsız snf=yüksek } \\
\text { cinsiyet=kız }\end{array}$ & 14.874 & 75.385 & 1.734 \\
\hline
\end{tabular}


Tablo 5' e göre, bağımlı öğrenme stili orta seviyede, bağımsız öğrenme stili yüksek seviyede olan 2. Sınıf öğrencilerinin \%76,92 olasılıkla öğrenme stilinin bağımsız olduğu söylenebilir. Aynı zamanda bu grup tüm örneklemin \% 11,89'unu oluşturmaktadır.

İşbirlikçi öğrenme stili orta seviyede, bağımlı öğrenme stili orta seviyede ve bağımsız öğrenme stili yüksek seviyede olan öğrencilerinin \%75,55 olasılıkla öğrenme stilinin bağımsız olduğu söylenebilir. Bununla birlikte, tüm örneklemin \% 10,29'u bu gruba aittir.

Ayrıca tüm örneklemin \% 12,12 sini oluşturan bir başka grup için şu birliktelik kuralından bahsedilebilir: Pasif öğrenme stili orta seviyede, bağımsız öğrenme stili yüksek seviyede olan 2. Sınıf öğrencileri, \%75,41 olasılıkla bağımsız öğrenme stiline sahiptir.

Bu başlık altındaki son birliktelik kuralı ise tüm örneklemin \% 14,87'sini oluşturmaktadır. Burada da, bağımsız öğrenme stili yüksek seviyede olan 2. sınıf kız öğrencilerinin \%75,38 olasılıkla öğrenme stilinin bağımsız olduğu söylenebilir.

Birliktelik kurallarında, güvenirlik (confidence) araştırmacının isteğine göre değiştirilebilmektedir. Sonuçlar da buna göre değişmektedir. Bu araştırmada, \% 75 ve üstü güvenirlik seçilmiş ve bu seçime göre 4 grup oluştuğu gözlemlenmiştir. Güvenirlik azaltılırsa daha fazla kural elde edilebilir. Ayrıca birliktelik kurallarında 1'in üzerindeki kaldıraç değeri (lift), değişkenler arasında kuvvetli ilişkileri gösterir (Pandey\& Pal, 2011). Bu çalışmada da 4 kuralda da bu değerin 1'den yüksek olduğu görülmektedir.

\% 75 ve üstü güvenirlik ile öğrenme stillerinin alt boyutları arasında birliktelik kurallarına bakıldığında ise tek kural bulunmuştur. Buna göre, işbirlikçi öğrenme stili ve bağımlı öğrenme stili orta seviyede ve bağımsız öğrenme stili yüksek seviyede olan öğrencilerin \%75,55 olasılıkla öğrenme stilinin bağımsız olduğu görülmektedir. Aynı zamanda bu grup tüm örneklemin \% 10,29'unu oluşturmaktadır ve kaldıraç değeri ise 1.738 dir.

\section{Sonuç ve Öneriler}

Analiz sonuçlarına göre, Grasha-Reichmann Öğrenme Stilleri Envanterine göre belirlenen baskın öğrenme stilleri ile bunların alt boyutları ve cinsiyet, öğrenim türü, sınıf derecesi gibi diğer değişkenler arasında veri madenciliği yardımıyla daha ayrıntılı ilişkiler kurulabildiği söylenebilir. Keza, literatürde bu ölçeğin kullanıldığı çalışmaların genelinde (Bilgin ve Durmuş, 2003; Karataş, 2004; Grasha at all, 2000 vb...), birtakım farklılıkları olsa da özetle öğrenme stilleri ile öğrenci başarısı arasındaki ilişkilerin araştırıldığı görülmektedir. Bu bağlamda veri madenciliği ile yapılan bu çalışmanın farklı bir bakış açısı getirdiği düşünülmektedir.

A ̆g grafiği yardımıyla öğrenme stillerinin alt boyutları arasında ilişkiler kurulmuştur. Örneğin pasif öğrenme stili ile bağımsız öğrenme stilinin düşük düzeyleri arasında ilişi olmadığı, işbirlikçi öğrenme stili düzeyi yüksek olan öğrencilerin bağımlı öğrenme stillerinin orta düzeyde olduğu, bağımsız öğrenme stillerinin ise yüksek düzeyde olduğu görülmüştür. Ayrıca, rekabetçi stil düzeyi, hem de bağımsız stil düzeyi yüksek olan öğrencilerin çokluğu ve de öğretmen adaylarında aynı anda bağımsız öğrenme stili ve işbirlikçi öğrenme stili yüksek olma ilişkisinin diğer düzeyler arasındaki ikili ilişkilerden daha anlamlı olduğu bu analiz ile anlaşılabilmektedir. Önceki çalışmalarda öğrenme stillerinin belirlenmesi için kullanılan modellerden ve ölçme araçlarından kaynaklanan çeşitli problemler ve tutarsızlıklar olduğu belirtilmektedir. Örneğin; öğrenme stilinin sabit ya da dinamik bir yapıda olmasına bağlı olarak, birçok öğrenme stili envanterinde, bireyler bir öğrenme stili içine yerleştirilmekte ve üç ya da dört öğrenme stilinin birinin elemanı olarak sınıflandırılmaktaydı. Bu tür durağan ve sabit yapılı bir yaklaşım birçok sorunu beraberinde getirebilmektedir. Bu yolla bireyler belli bir stil çatısı altına alınmakta ve diğer stillerdeki özellikleri ihmal edilmektedir. Silver, Strong\& Perini (1997), Denig (2004) ve McCarthy, Germain\&Lippitt (2006) gibi araştırmacılar tekil yapıdaki ve değişmeyen, sabit olan bir öğrenme stili anlayışına karşın öğrenme stilinin çoklu yapıda ve baskınlık kavramının olduğunu ve değişebileceğini bildirmektedirler. Garner (2000), Kolb'ün öğrenme stili modelinde Tyler'ın "possibility processing" yaklaşımını doğru kullanılmadığını ve öğrenme stillerinin esnek olmadığını ve sabit bir yapının olduğunu ileri sürmektedir. Kolb, öğrenme stilinin sabit (fixed traits) olduğu yönünde eleştirileri kabul etmeyip, 9 farklı öğrenme stilini içinde barındıran 
öğrenme uzayı (learning space) kavramını ortaya koymuştur. Öğrencilerin öğrenme stilleri ve öğrenme ortamları arasındaki etkileşimi anlamak için bir çerçeve olarak bu kavramı geliştirilmiştir (Kolb \& Kolb, 2005a). Söylendiği gibi, bu uzayda 9 farklı öğrenme stilinden söz edilmektedir. Narlı ve arkadaşlarının (2011) çoklu zeka ile öğrenme stilleri arasındaki ilişkiyi kaba küme kuramı ile araştırdıkları çalışmada, Kolb öğrenme stiline göre belirlenen 4 temel baskın öğrenme stilinin (D, Ö, A, Y) yanında tekil öğrenme stiline sahip olmayan bireylerin olduğu görülmektedir. Yani çoklu baskın öğrenme stiline sahip bireylerin varlı̆̆1 kanıtlanmaktadır. Örneğin öğrenme stili ölçeğinin analizi sonucunda değiştiren öğrenme stiline sahip olan bir birey, ilgili çalışmada çoklu zekâ alanları göz önüne alındıktan sonra, kaba küme veri analizinde potansiyel olarak özümseyen, ayrıştıran ya da yerleştiren öğrenme stiline de sahip olarak tanımlanmaktadır. Bu çalışmada da baskın öğrenme stili yanında diğer alt boyutlar arasında ilişki kurulabilmiştir.

Öğrenme stilinin belirlenmesinde geçmişten günümüze farklı yaklaşımlar denenmektedir. Bu yaklaşımlardan birinde, Yannibelli, Godoy \& Amandi (2006), öğrencilerin eylemlerine (actions) dayalı öğrenme stillerinin belirlenmesinde bir genetik algoritma yaklaşımı geliştirmişler ve uygulamışlardır. Ayrıca Kazu \& Özdemir (2009), Özek, Akpolat \& Orhan (2010), Uysal (2010) yaptıkları çalışmalarda öğrencilerin öğrenme stillerinin bulanık mantık kullanarak modellenebileceğini göstermiş ve öğrenme stili ile ilgili kurallar oluşturulmuştur. Narlı ve arkadaşlarının yaptığı çalışmada (2011), öğrencilerin öğrenme stillerinin belirlenmesinde, bulanık küme yaklaşımına ek olarak belirsizlik derecesi ve kesinlik derecesi gibi verilerden de yararlanılmasının yararlı olduğu düşünülmüştür. Bu çalışmada da veri madenciliği tekniklerinden olan karar ağaçları yardımıyla, öğrenme stilleri alt boyutları arasında karar kuralları oluşturulmaya çalışılmıştır. Örneğin, Grasha-Riechmann Öğrenme Stili Alt Boyutları için kurulan ağaç modelinde şu kuralı söyleyebiliriz: "bağımsız öğrenme stili yüksek düzeyde (Node 9) olan bir öğrencinin, bağımlı öğrenme stili düşük veya orta düzeyde (Node 10) ise ve işbirlikçi öğrenme stili düşük veya orta düzeyde (Node 11) ise bu öğrenci \% 78,57 olasılıkla bağımsız öğrenme stiline sahiptir. Diğer karar düğümleri için de yapılabilecek bu tür yorumlar ile öğrencilerin öğrenme stillerinin alt boyutları arasında ayrıntılı ilişkiler kurulabilir.

Yapılan çalışmanın matematik öğretmen adayları ile yürütülmesi, çalışmanın sınırlılığı olarak görülebilir. İleride yapılacak olan araştırmalarda farklı örneklem ve yaş gruplarındaki bireylerin bu yaklaşım ile farklı öğrenme stilleri envanterleri arasında, öğrenme stilleri ile çoklu zekâ alanları, tutum vb... gibi değişkenler arasında ilişkiler araştırılabilir. Öğrenme stillerinin belirlenmesine yönelik önerdiğimiz bu analiz yaklaşımının farklı araştırmacılar tarafından kullanılması, sınırlılıkları, diğer yaklaşımlarla olan ortak ve ayrık yönlerinin ortaya konulması yönünde faydalı bilgiler ortaya çıkaracaktır.

Bütün bu sonuçlar öğrenme yaklaşım, yol-yöntem uygulamalarında değişik öğrenme stillerine yönelik etkinlikler kullanılmasının, öğrencinin potansiyel olarak dâhil olduğu öğrenme stilini de aktif hale getirebileceğini göstermektedir. Bu yolla belki bireyin öğrenme stilinin değişme şansı da yakalanabilecektir.

\section{Kaynakça}

Ali, R.M., \& Kor, L.K. (2007). Association between brain hemisphericity, learning styles and confidence in using graphics calculator for mathematics. Euraisa Journal of Mathematics, Science \& Technology Education, $3(2), 127-131$.

Amarshi, S., \& Conati, C. (2009). Combining unsupervised and supervised classification to build user models for exploratory learning environments. Journal of Educational Data Mining, 1(1), 1-54

Aydın, Ş. (2007). Veri madenciliği ve Anadolu üniversitesi uzaktan eğitim sisteminde bir uygulama. Yayınlanmamış Doktora Tezi, Anadolu Üniversitesi Sosyal Bilimler Enstitüsü

Baker, R.S.J.D. (in press). Data Mining for Education. To appear in McGaw, B., Peterson, P., Baker, E. (Eds.) International Encyclopedia of Education (3rd edition). Oxford, UK: Elsevier.

Baker, R.S.J.D., Corbett, A.T., Roll I., \& Koedinger, K.R. (2008). Developing a generalizable detector of hen students game the system. User Modeling and User-Adapted Interaction, 18 (3), 287-314. 
Beck, J. (2005). Engagement tracing: using response times to model student disengagement. In Proceedings of the International Conference on Artificial Intelligence in Education.

Becker, K., C. Ghedini and E.L. Terra (2000) Using KDD to analyze the impact of curriculum revisions in a Brazilian university, SPIE 14th Annual International Conference on Aerospace/Defesense, Sensing, Simulation and Controls' da sunulan bildiri. 412- 419, Orlando.

Bilen, Ö., Hotaman, D., Aşkın, Ö. E., \& Büyüklü, A. H. (2014). LYS Başarılarına Göre Okul Performanslarının Eğitsel Veri Madenciliği Teknikleriyle İncelenmesi: 2011 İstanbul Örneği. Ĕ̆itim Ve Bilim. 39(172), Geniş Ölçekli Test Uygulamaları Özel Sayısı

Bilgin, İbrahim, Durmuş, Soner. (2003). Öğrenme Stilleri ile Öğrenci Başarısı Arasındaki İlişki Üzerine Karsılaştırmalı Bir Araştırma. Kuramdan Uygulamaya Eğitim Bilimleri Dergisi. 3(2): 381-393

Curry, L. (1990). A critique of the research on learning styles. Educational Leadership, October, 50-57.

Çelik, M. (2009). Veri Madenciliğinde Kullanılan Sınıflandırma Yöntemleri ve Bir Uygulama. Yayınlanmamış Yüksek Lisans Tezi. İstanbul Üniversitesi Sosyal Bilimler Enstitüsü.

Güntürkün, .(2007). A Comprehensive Revıew Of Data Mining Applications in Quality Improvement And A Case Study. Yayımlanmamış Yüksek Lisans Tezi. Orta Doğu Teknik Üniversitesi.

Çepni, S. (2009). Araştırma ve Proje Çalışmalarına (Geliştirilmiş 4. baskı).

Denig, S. (2004). Multiple intelligences and learning styles: two complementary dimensions. Teacher College, 106(1), 96-111.

Diaz, D. P., \& Cartnal, R. B. (1999). Students' learning styles in two classes: Online distance learning and equivalent on-campus. College teaching, 47(4), 130-135.

Dolgun, L. E. (2006). A Decision Matrix Based Method for Determining Priorities of Quality Improvement Projects in Manufacturing with Inspection Error and Rework. Orta Doğu Teknik Üniversitesi

Dunn, R. (1983). Can students identify their own learning style? When it's important to them they can. Educational Leadership, 40(5), 60-62.

Elçi, A.N. (2008). Öğrenme stillerine uygun olarak seçilen öğrenme yöntemlerinin ö̆grenci başarısına, matematiğe yönelik tutumuna ve kaygısına etkileri. Yayımlanmamış Doktora Tezi. Dokuz Eylül Üniversitesi Eğitim Bilimleri Enstitüsü, İzmir.

Emel G.G., Taşkın Ç., Tok A. (2005). Pazarlama Stratejilerinin Oluşturulmasında bir Karar Destek Ağacı, Birliktelik Kurah Madenciliğ̈i, Dokuz Eylül Üniversitesi Sosyal Bilimler Enstitüsü Dergisi

Ertekin, E., Dilmaç, B., \& Yazıc1, E. (2009). The relationship between mathematics anxiety and learning styles of preservice mathematics teachers. Social Behavior and Personality, 37(9), 1187-1196.

Fer, S. (2003). Matematik, fizik ve kimya öğretmenliği öğrencilerinin öğrenme biçemlerine göre kolay öğrendikleri öğrenme etkinlikleri. Çağdaş Eğitim, 28(304), 33-43.

Garner, I. (2000). Problems and inconsistencies with Kolb's learning styles. Educational Psychology, 20(3), 341348.

Grasha, Anthony. (2002). Teaching With Style. 2.bs. USA: Alliance Publishers

Grasha, Anthony, Natalia Yangarber-Hicks. (2000). Integrating Teaching Styles and Learning Styles with Instructional Technology. College Teaching. 48:2-10

Güçle, G. (2010). Veri ambarı ve veri madenciliği teknikleri kullanılarak öğrenci karar destek sistemi oluşturma. Yayınlanmamış yüksek lisans tezi. Denizli, Pamukkale Üniversitesi Fen Bilimleri Enstitüsü.

Karasar, N. (2008). Bilimsel araştırma yöntemi (18.Baskı). Ankara: Nobel Yayın Dağıtım.

Karataş, Erinç. (2004). Bilgisayara Giriş Dersini Veren Öğretmenlerin Öğretme Stilleri ile Dersi Alan Öğrencilerin Öğrenme Stillerinin Esleştirilmesinin Öğrenci Başarısı Üzerindeki Etkisi. Gazi Üniversitesi Eğitim Bilimleri Enstitüsü Bilgisayar Eğitimi Ana Bilim Dalı. Yüksek Lisans Tezi 
Kazu, İ. Y., \& Özdemir, O. (2009). Öğrencilerin bireysel özelliklerinin yapay zeka ile belirlenmesi (Bulanık mantık örneği). Akademik Bilişim 2009 Konferansı, 11-13 Şubat 2009, Harran Üniversitesi, Şanlıurfa, 457466 (Erişim tarihi: 29.12.2010).

Koçak, T. (2007). Illköğretim 6.7.8. Sinıf Öğrencilerinin Öğrenme Stilleri ve Akademik Başarılarn Arasındaki İlişki, Yüksek Lisans Tezi, Gaziantep Üniversitesi Sosyal Bilimler Enstitüsü, Eğitim Bilimleri Ana Bilim Dalı, Gaziantep.

Kolb, D.A. (1984). Experiential learning: experience as the source of learning and development http://academic.regis.edu/ed205/kolb.pdf

Kolb, Y.A., \& Kolb, D.A. (2005a). Learning styles and learning spaces: enhancing experiential learning in higher education. Academy of Management Learning \& Education, 4(2), 193-212.

Kolb, A.Y., \& Kolb, D.A. (2005b). The Kolb learning style inventory - version 3.12005 technical specifications. Boston, MA: Hay Group, Hay Resources Direct.

Kumar, S. A \& Dr. Vijayalakshmi (2013). Discerning learner's erudition using data mining techniques. M.NInternational Journal on Integrating Technology in Education (IJITE) 2(1), March

Kuzgun, Y. (2006). Zeka ve yetenekler. (Ed. Kuzgun Y. \& Deryakulu, D.), Eğitimde Bireysel Farkllıklar. 13-73. Ankara: Nobel Yayın Dağıtım.

Küçükkaragöz, H., et.al. (2009). İlköğretim matematik, fen bilgisi ve Türkçe öğretmen adaylarının öğrenme stilleri ve problem çözme becerilerinin incelenmesi. 1. Uluslar arası Türkiye Ĕ̆itim Araştırmaları Kongresi, Çanakkale Üniversitesi, Çanakkale.

McCarthy, B., Germain, C.S., \& Lippitt, L. (2006). The 4MAT research guide, reviews of literature on individual differences and hemispheric specialization and their influence on learning. Illinois: About Learning Incorporated.

Michael J. Berry , Gordon Linoff, Data Mining Techniques: For Marketing, Sales, and Customer Support, John Wiley \& Sons, Inc., New York, NY, 1997

Narli, S. (2010). An alternative evaluation method for likert type attitude scales: rough set data analysis. Scientific Research and Essays, 5(6), 519-528

Narli, S., \& Ozcelik, Z.A. (2010). Data mining in topology education: Rough set data analysis. International Journal of the Physical Sciences, 5(9), 1428-1437

Narli, S., Ozgen, K., \& Alkan, H. (2011), In the context of multiple intelligences theory, intelligent data analysis of learning styles was based on rough set theory. Learning and Individual Differences, 21, 613618.

Narli, S., Yorek, N., Sahin, M., \& Uşak, M. (2010), Can we make definite categorization of student attitudes? A rough set approach to investigate students' implicit attitudinal typologies toward living things. Journal of Science Education and Technology, 19, 456-469.

Orhun, N. (2007). An investigation into the mathematics achievement and attitude towards mathematics with respect to learning style according to gender. International Journal of Mathematical Education in Science and Technology, 38(3), 321-333.

Özek, M.B., Akpolat, Z.H., \& Orhan, A. (2010). Web tabanlı akıllı öğretim sistemlerinde tip-2 bulanık mantık kullanarak öğrenci öğrenme stili modelleme. Fırat Üniversitesi Mühendislik Bilimleri Dergisi, 22(1), 37-44.

Özer, B. (1998). Öğrenmeyi Öğretme, (Ayhan Hakan (Ed.). Ĕ̆itim Bilimlerinde Yenilikler (ss. 146-164), Eskişehir: Anadolu Üniversitesi Açıköğretim Fakültesi İlköğretim Öğretmenliği Lisans Tamamlama Programi.

Peker, M. (2009). Pre-service teachers' teaching anxiety about mathematics and their learning styles. Eurasia Journal of Mathematics, Science and Technology Education, 5(4), 335-345. 
Peker, M., Mirasyedioğlu, Ş., \& Aydın, B. (2004). Matematik öğretmenlerinin dikkate alabilecekleri öğrenme stilleri: McCarthy modeli. Milli Eğitim Dergisi, 163. http://yayim.meb.gov.tr/dergiler/163/peker.htm (Erişim Tarihi: 03.05.2010).

Perry, C., \& Ball, I. (2004). Teacher subject specialisms and their relationships to learning styles, psychological types and multiple intelligences: implications for course development. Teacher Development, 8(1), 9-28.

Silver, H., Strong, R., \& Perini, M. (1997). Integrating learning styles and multiple intelligences. Educational Leadership, 55(1), $22-27$.

Sison, R., Numao, M., \& Shimura, M. (2000). Multistrategy discovery and detection of novice programmer errors. Machine Learning, 38, 157-180.

Şentürk, F. (2010). 7.Sınıf Ö̆grencilerinin Öğrenme Stilleri İle Matematik Öğretmenlerinin Öğretme Stillerinin Öğrencilerin Matematik Dersi Başarısı Üzerine Etkisi. Yayımlanmamış Yüksek Lisans Tezi. Balıkesir Üniversitesi Fen Bilimleri Enstitüsü.

Şimşek, A. (2006). Öğrenme biçimi. (Ed. Kuzgun Y. \& Deryakulu, D.), Eğitimde Bireysel Farkllıklar. 97-138. Ankara: Nobel Yayın Dağıtım.

Şimşek, Ö. F. (2007). Yapısal Eşitlik Modellemesine Giriş: Temel İlkeler ve Lisrel uygulamaları. Ankara: Ekinoks Yayınları

Tomlinson, C.A. (2007). Öğrenci gereksinimlerine göre farklılaştırılmış eğitim.(Çev.) İstanbul: Redhouse Eğitim Yayınları

Unesco (2004). Changing teaching practice using curriculum differentation to respond to students' diversity. Paris: Unesco.

Uysal, M.P. (2010). Öğrenme stillerinin bulanık mantıkla modellenmesi. 4th International Computer $\mathcal{E}$ Instructional Technologies Symposium, Selçuk University, Konya, Turkey, 1040-1045.

Uzuntiryaki, E., Bilgin, İ. \& Geban, Ö. (2003). The effect of learning styles on high school students' achievement and attitudes in chemistry. Paper Presented at the Annual Meeting of the National Association for Research in Science Teaching. Philadelphia, PA, (ERIC Document Reproduction Service No: ED 475 483).

Yannibelli, V., Godoy, D., \& Amandi, A. (2006). A genetic algorithm approach to recognise students' learning styles. Interactive Learning Environments, 14(1), 55-78.

Yorek, N., \& Narli, S. (2009). Modeling of cognitive structure of uncertain scientific concepts using fuzzyrough sets and intuitionistic fuzzy sets: example of the life concept. International Journal of Uncertainty, Fuzziness and Knowledge-Based Systems, 17(5), 747-769.

Zaiane, O. (2002). Building a Recommender Agent for e-Learning Systems. In Proceedings of the International Conference on Computers in Education. 